\title{
Physiology of acid-base balance in bovines with diarrhea backgrounds from Monteria, Colombia
}

\author{
Fisiología del estado ácido-básico en bovinos con antecedentes \\ diarreicos de Montería, Colombia
}

\author{
César Betancur H, ${ }^{1 *}$ M.Sc, Yordan Martínez A, ${ }^{2}$ Ph.D, Luis Cruz M, ${ }^{3}$ Esp.
}

\begin{abstract}
${ }^{1}$ Universidad de Córdoba, Facultad de Medicina Veterinaria y Zootecnia. Departamento de Ciencias Pecuarias. Montería, Colombia. ${ }^{2}$ Universidad de Granma, Facultad de Medicina Veterinaria. Centro de Estudios de Producción Animal. Bayamo, Granma. Cuba. ${ }^{3}$ Universidad Nacional de Colombia, Facultad de Medicina, Unidad de Fisiología. Bogotá, Colombia. *Correspondencia: betanci@yahoo.com
\end{abstract}

Received: April 2014; Accepted: January 2015.

\begin{abstract}
Objective. Evaluate the acid-base balance $(A B B)$ in bovines with diarrheic backgrounds in four areas of Montería, Colombia. Materials and methods. From a total of 300 pregnant cows, 60 were selected with their newborns. A direct inspection was performed of vital signs on the calves and the ABB indicators were determined using a gasometric method. Data were processed by means of descriptive statistics and the Duncan test was used to differentiate between the averages. The degree of association was established between the ABB indicators in cows and calves by using the Pearson correlation and a comparison of proportions was performed on the indexes of the newborns. Results. Regarding the cows, the ABB indicators were found within the reference values; however, in the calves the $\mathrm{pH}, \mathrm{pCO}_{2} \mathrm{HCO}_{3}^{-}$, the anion gap (AG) and the bases excess (BE) varied. A correlation was found between $A G, B E$ and metabolic hydrogen ions $(M * H)$. The $A G$ in cows and calves showed notable differences $(p<0.05)$ among the farms in the study. According to the numeric classification system, the suction reflect indicated a greater percentage of calves in group one. Conclusions. The ABB analyte measurement in cows was similar to the consulted reference; however, in calves some analytes did not coincide. This suggests metabolic acidosis in newborn calves due to the increase of AG and the decrease of $\mathrm{BE}$. Additionally, its correlation with $\mathrm{M} * \mathrm{H}$ opens the possibility of new proposals to determine $A B B$ in bovines.
\end{abstract}

Key Words: Metabolic acidosis, anions, diarrhea, metabolic hydrogen ions (Source: $C A B$ ).

\section{RESUMEN}

Objetivo. Evaluar el equilibrio ácido-básico (EAB) en bovinos con antecedentes diarreicos de cuatro zonas de Montería, Colombia. Materiales y métodos. De un total de 300 vacas preñadas se seleccionaron 60 vacas y sus recién nacidos. Se realizó una inspección directa de los signos vitales en terneros y los indicadores del EAB se determinaron mediante técnica gasométrica. Los datos se procesaron mediante estadística descriptiva y para la diferencia entre medias se empleó la prueba de Duncan. El grado de asociación se estableció entre los indicadores del EAB en vacas y terneros mediante la correlación de Pearson y una comparación de proporciones se realizó en los índices del recién nacido. Resultados. En las vacas, los indicadores del EAB se encontraron dentro de los valores 
de referencia; sin embargo, en los terneros varió el $\mathrm{pH}, \mathrm{pCO}_{2}, \mathrm{HCO}_{3}{ }^{-}$, la brecha aniónica ( $\mathrm{AG}$ ) y el exceso de bases (EB). Se encontró correlación entre $A G, E B$ e hidrogeniones metabólicos $\left(H^{+} M\right)$. El $A G$ en vacas y terneros indicó diferencias notables $(p<0.05)$ entre las fincas de estudio. De acuerdo con el sistema de calificación numérica, el signo reflejo de succión indicó el mayor porcentaje de terneros en el grupo uno. Conclusiones. La medición de los analitos del EAB en vacas fue similar a la referencia consultada; sin embargo, en terneros no coincidió con algunos analitos. Se sugiere acidosis metabólica en los terneros recién nacidos por el aumento del AG y descenso del EB, además, su correlación con los $\mathrm{H}^{+} \mathrm{M}$ abre la posibilidad de nuevas propuestas para la determinación del $E A B$ en bovinos.

Palabras clave: Acidosis metabólica, aniones, diarrea, hidrogeniones metabólicos (Fuente: CAB).

\section{INTRODUCTION}

Diverse alterations of acid-base balance (ABB) are found in bovines, among which metabolic acidosis is particularly frequent (1). The diarrheic syndrome is the most frequent cause of metabolic acidosis in calves, especially during the neonatal period (first 28 days of life) (2). The cause of neonatal diarrhea is multifactorial; the calves at birth are susceptible to being agammaglobulinemic, and therefore they tend to suffer specific or secondary infections unless they quickly ingest colostrum (3); but beyond the causes of diarrhea, a hydroelectrolytic imbalance develops that generally causes dehydration, acidosis, and frequently death (4).

The first physiological model to evaluate $A B B$ was proposed in 1908 by Lawrence Henderson. This author worked on the concept of acid as a donator of protons and hydrogen ions (Arrhenius definition 1890), (5). In 1916, Hasselbalch converted the Henderson equation into a logarithmic expression, which describes this known equation as Henderson-Hasselbalch $(\mathrm{HH})$; where the $\mathrm{ABB}$ is obtained from measuring the $\mathrm{HCO}_{3}^{-} / \mathrm{H}_{2} \mathrm{CO}_{3}$ buffer pair (6).

The $\mathrm{HH}$ equation has been a valuable tool to help understand the physiology of the acid base balance and is used in the clinical management of $A B B$ disorders in ruminants; this equation explains the $\mathrm{pH}$ changes due to the changes in the concentration of $\mathrm{HCO}_{3}^{-}$and the pressure values of $\mathrm{CO}_{2}\left(\mathrm{pCO}_{2}\right)(7)$.

For many years, the bicarbonate/carbonic acid system has been kept in mind to define the terms acidosis and alkalosis, using the total content of $\mathrm{CO}_{2}$ and bicarbonate as reference points to classify respiratory or metabolic alterations (8). However, the $\mathrm{HH}$ equation does not separate the respiratory component from the metabolic one.

In 1948, Singer and Hastings (9) proposed the concept of the buffer base (BB) from the concept of the electroneutrality of solutions and

\section{INTRODUCCIÓN}

Diversas alteraciones del estado ácido-base (EAB) son encontradas en bovinos, dentro de las cuales es particularmente frecuente la acidosis metabólica (1). El síndrome diarreico es la causa más frecuente de acidosis metabólica en terneros, en especial durante el período neonatal (primeros 28 días de vida) (2). La causa de diarrea neonatal es multifactorial; los terneros al nacer son susceptibles a ser agammaglobulinémicos, por lo que tienen tendencia a sufrir infecciones específicas o secundarias, a menos que ingieran pronto el calostro (3); pero más allá de las causas de diarrea, se desarrolla un desbalance hidroelectrolítico que por lo general causa deshidratación, acidosis y en muchas ocasiones la muerte (4).

El primer modelo fisiológico para evaluar el EAB fue propuesto en el año de 1908 por Lawrence Henderson. Este autor trabajó en el concepto de ácido como un donador de protones o hidrogeniones (definición de Arrhenius 1890), (5). En 1916, Hasselbalch convirtió la ecuación de Henderson a su expresión logarítmica, lo que describe de esta forma la conocida ecuación de Henderson-Hasselbalch $(\mathrm{HH})$; donde se obtiene el EAB a partir de mediciones del par tampón $\mathrm{HCO}_{3}^{-} / \mathrm{H}_{2} \mathrm{CO}_{3}(6)$.

La ecuación de $\mathrm{HH}$ ha sido una herramienta valiosa para ayudar a comprender la fisiología del estado ácido base y se emplea en el manejo clínico de los trastornos del EAB en rumiantes; dicha ecuación explica los cambios en el $\mathrm{pH}$ con base en los cambios en la concentración de $\mathrm{HCO}_{3}^{-}$y los valores de la presión de $\mathrm{CO}_{2}\left(\mathrm{pCO}_{2}\right)(7)$.

Durante muchos años, el sistema de bicarbonato/ ácido carbónico se ha tenido en cuenta para definir los términos acidosis y alcalosis, tomando el contenido total de $\mathrm{CO}_{2}$ y el bicarbonato como los puntos de referencia para clasificar las alteraciones en respiratorias o metabólicas (8). Sin embargo, la ecuación de HH no separa el componente respiratorio del metabólico. 
interpreting that anions behaves as acids; thus, in 1960 Anderssen et al (10) introduced the term Excess of Bases (BE) as an independent variable of the $\mathrm{pCO}_{2}$. The $\mathrm{BE}$ represents the metabolic component or change of non-volatile acids or bicarbonate, calculated under ideal conditions, that is, with a $\mathrm{pCO}_{2}$ of $40 \mathrm{mmHg}$; since then the $\mathrm{BB}$ and the BE were used to support the diagnosis of the metabolic component (11).

The concept of anionic gap or Anion Gap (AG) arose in the 1970 s as a way to classify metabolic acidosis and explain its causes (12). The importance of the calculation is that it allows differentiating of metabolic acidosis into two main types: metabolic acidosis with elevated AG or normal AG, caused by a loss of bicarbonate (13).

Recently, Cruz et al (14) of the Physiology Unit of the Medical Faculty of the Universidad Nacional of Colombia proposed differentiating hydrogen ions $\left(\mathrm{H}^{+}\right)$that generate blood $\mathrm{pH}$ in metabolic $\mathrm{H}^{+}\left(\mathrm{M}^{+} \mathrm{H}\right)$ and $\mathrm{H}^{+}$derived from $\mathrm{CO}_{2}\left(\mathrm{H}^{+}-\mathrm{CO}_{2}\right)$. Due to this, the total hydrogen ions (Htot) are those that are derived from the $\mathrm{pH}$ value and that classically corresponds to the antilogarithm of the negative value of $\mathrm{pH}$; then, knowing the slope of the relationship between $\mathrm{pH}$ and $\mathrm{PCO}_{2}$, the $\mathrm{H}^{+}-\mathrm{CO}_{2}$ (15) are obtained.

These latter approaches have been denominated as "semi-quantitative" and have an important place in clinical use, and would be taken as objective information. There are other parameters that are considered to be subjective information; those that could estimate the presence of acidosis in a newborn calf; the hypothesis that arises about the possibility of determining the ABB in a calf in field conditions, without recurring to the determination of blood gases.

In the studies consulted, there was not enough information found about assessing ABB during the establishment of enteric syndrome in bovines, and therefore the objective of this study was to determine the $A B B$ in cow blood with diarrheic background, and their respective calves, at four farms in the department of Córdoba, Colombia, to establish if there are differences between those indicators in the farms studied, and evaluate if there is a correlation between the classically diagnosed $\mathrm{ABB}$ based on the $\mathrm{HH}$ equation, the $B E$, alterations in $A G$ and with a new proposal for $\mathrm{M}^{+} \mathrm{H}$, as well as analyzing the indexes of the newborn.

\section{MATERIALS AND METHODS}

Type of study. A prospective cross-sectional study was done.
En 1948, Singer y Hastings (9) propusieron el concepto de base búfer (BB), partiendo del principio de electroneutralidad de las soluciones y de interpretar que los aniones se comportan como ácidos; así en 1960, Anderssen et al (10), introdujeron el término Exceso de Bases (EB), como variable independiente de la $\mathrm{pCO}_{2}$. El EB representa el componente metabólico o cambio de los ácidos no volátiles o del bicarbonato, porque se calcula bajo condiciones ideales, es decir, con una $\mathrm{pCO}_{2}$ de $40 \mathrm{mmHg}$; desde entonces la $\mathrm{BB}$ y el EB se convirtieron en el punto de apoyo para el diagnóstico del componente metabólico (11).

El concepto de brecha aniónica o Anion Gap (AG) surge en la década de los 70 como una forma de clasificar las acidosis metabólicas y explicar las causas de las mismas (12). La importancia de su cálculo, radica en que permite diferenciar las acidosis metabólicas en dos tipos principales: acidosis metabólica con AG elevado, lo que indica que la acidosis está causada por ganancia de ácidos o con AG normal, ocasionada por pérdida del bicarbonato (13).

Recientemente, Cruz et al (14) de la Unidad de Fisiología de la Facultad de Medicina de la Universidad Nacional de Colombia, proponen diferenciar los hidrogeniones $\left(\mathrm{H}^{+}\right)$que generan el $\mathrm{pH}$ sanguíneo en $\mathrm{H}^{+}$metabólicos $\left(\mathrm{H}^{+} \mathrm{M}\right)$ e $\mathrm{H}^{+}$ derivados del $\mathrm{CO}_{2}\left(\mathrm{H}^{+}-\mathrm{CO}_{2}\right)$. Para esto se denominan hidrogeniones totales (Htot) los derivados del valor de $\mathrm{pH}$ y clásicamente corresponden al antilogaritmo del valor negativo del $\mathrm{pH}$; luego conociendo la pendiente de la relación entre $\mathrm{pH}$ y $\mathrm{PCO}_{2}$ se obtienen los $\mathrm{H}^{+}-\mathrm{CO}_{2}$ (15).

Estos últimos enfoques, que han sido denominados como "semicuantitativos", han ganado un espacio importante en el uso clínico, y serían tomados como información objetiva. Existen otros parámetros que son considerados como información subjetiva; los cuales podrían estimar la presencia de la acidosis en un ternero recién nacido; surge la hipótesis de si es posible determinar el EAB en el ternero en condiciones de campo, sin recurrir a la determinación de los gases sanguíneos.

En los trabajos consultados no se encontró información suficiente de la valoración del EAB durante la instauración del síndrome entérico en bovinos, por ello el objetivo del presente estudio fue determinar el EAB en sangre de vacas con antecedentes diarreicos y sus respectivos terneros en cuatro fincas del departamento de Córdoba, Colombia; establecer si hay diferencias entre estos indicadores en las fincas de estudio, evaluar si hay correlación entre el EAB diagnosticado clásicamente con base en 
Study site. The work was done in the municipality of Montería, department of Córdoba, located at $8^{\circ} 45^{\prime}$ north and $75^{\circ} 53^{\prime}$ west; the average temperature was between 28 and $35^{\circ} \mathrm{C}, 85 \%$ relative humidity, with an annual precipitation of 1.200 to $1.500 \mathrm{~mm}$, and an altitude of 18 meters above sea level. The municipal area is $3.043 \mathrm{~km}^{2}$, with 27 divisions. Its northern border is Puerto Escondido, San Pelayo and Cereté; the eastern, San Carlos and Planeta Rica; the southern, Tierralta and Valencia; and the western with the department of Antioquia and Canalete.

Study population. Animals from four farms located in the municipality of Montería were used, with a history of diarrheic symptoms frequent in calves. The sample was composed of 300 pregnant cows in good condition, which corresponded to $10 \%$ of the population of four farms $(A=70 ; B=50 ; C=60$ y $D=120)$ from the region. The calves were born over a two month period of time, so the weather had no influence during that time period.

Sample size calculation. From a population of 300 cows, a sample of $n$ size was selected to determine the following formula:

$$
n=\frac{n_{0}}{1+\frac{n_{0}}{N}} \quad \text { with } \quad n_{0}=\frac{Z^{2} P(1-P)}{E^{2}}
$$

Where $Z$ corresponds to the percentile of the normal distribution that will be tested at 90 , $91,92,93,94$ and $95 \%$. P corresponds to the proportion, in this case unknown, of animals with a certain trend, which was considered as being equal to 0.5 given that it provides a greater sample size. $E_{\text {, }}$ is the maximum possible error that would be tested at levels 1, 2, 3, 4, 5, 6, 7, 8,9 and 10. $\mathrm{N}=300$. According to data reported by the Colombian Cattle Federation (FEDEGAN), in 2007 the bovine population in the municipality of Montería was 178.320 females older than two years (16); this was considered $n$.

The bovines in these areas are mostly composed of Zebu crossbred with European breeds, mixed: Zebu $x$ Holstein and Brown Swiss.

To determine the size of the sample, a normal distribution table was used, with a statistical reliability rate of $94 \%$ and with a maximum allowed error rate of $5 \%$, and the size of the final sample was 60 animals. Sixty pregnant cows and their respective offsprings were evaluated in the four farms that were selected.

Taking and processing the sample. After disinfecting the area and subjecting the animal adequately, $5 \mathrm{ml}$ of blood was obtained from the la ecuación de $\mathrm{HH}$, el EB, las alteraciones en el AG y con la nueva propuesta de $\mathrm{H}^{+} \mathrm{M}$, así como analizar los índices del recién nacido.

\section{MATERIALES Y MÉTODOS}

Tipo de estudio. Se realizó un estudio prospectivo de corte transversal.

Sitio de estudio. El trabajo se realizó en el municipio de Montería, departamento de Córdoba, ubicado a $8^{\circ} 45^{\prime}$ de latitud norte y a $75^{\circ} 53^{\prime}$ de longitud oeste; la temperatura promedio osciló entre 28 y $35^{\circ} \mathrm{C}$, humedad relativa del $85 \%$, con una precipitación anual de 1.200 a $1.500 \mathrm{~mm}$ y una altitud de $18 \mathrm{msnm}$. El área municipal es de $3.043 \mathrm{~km}^{2}$, conformado por 27 corregimientos. Limita al norte con Puerto Escondido, San Pelayo y Cereté; al este con San Carlos y Planeta Rica; al sur con Tierralta y Valencia; y al oeste con el departamento de Antioquia y Canalete.

Población objeto de estudio. Se utilizaron los animales de cuatro fincas ubicadas en el municipio de Montería, con antecedentes de cuadros diarreicos frecuentes en terneros. La muetra estaba conformaba por 300 vacas preñadas con buena condición, las cuales correspondieron al $10 \%$ de la población de cuatro fincas $(A=70 ; B=50 ; C=60$ y $D=120$ ) de la región. Los terneros nacieron en un lapso de 2 meses, de tal manera que no hubiera influencia del clima en el tiempo.

Cálculo del tamaño de la muestra. A partir de la población de 300 vacas se seleccionó una muestra de tamaño $n$ determinado por la siguiente fórmula:

$$
n=\frac{n_{0}}{1+\frac{n_{0}}{N}} \text { Con } n_{0}=\frac{Z^{2} P(1-P)}{E^{2}}
$$

Donde $Z$ corresponde al percentil de la distribución normal que se probará a los niveles $90,91,92$, 93, 94 y $95 \%$. P, corresponde a la proporción, en este caso desconocida, de animales con una cierta característica, este se tomará igual a 0.5 dado que arroja el mayor tamaño de muestra. $E$, es el error máximo permisible y se probará a los niveles $1,2,3,4,5,6,7,8,9$ y $10 . N=300$. Según los datos reportados por la Federación Colombiana de Ganaderos (FEDEGAN), para el año 2007 la población bovina del municipio de Montería estuvo compuesta por 178.320 hembras mayores de dos años (16); este dato fue tomado como $n$.

Las especies bovinas de estas zonas están compuestas principalmente por animales cebuínos cruzados con razas europeas, mestizas: cebú x Holstein y Pardo Suizo. 
umbilical vein of the calves after birth without allowing them to suck colostrum and in the coccygeal vein of the cows. The procedure was done with commercial heparinized syringes (200 $\mu$ l of sodium heparin), bending the needle to avoid forming bubbles, and the samples were held on ice and were analyzed within two hours. The identifying data were recorded on individual medical record sheet. The presence of diarrhea syndrome was observed between 8-12 hours after birth. To perform the procedures described above, the regulations contained in bill 84 of 1989 related to animal welfare were observed (17).

A direct inspection was performed of vital signs on calves using the table 1 (18) as well as the laboratory variables needed to perform ABB calculations by means of an ionogram and the gasometric method.

A Rapidlab 348 (Bayer Lab. Germany) apparatus was used for blood gases, which works with selective direct ion electrodes and measuring bands for the results of $\mathrm{pCO}_{2}, \mathrm{Na}^{+}, \mathrm{K}^{+}, \mathrm{Cl}^{-}$and $\mathrm{pH}$. Bicarbonate calculation and $\mathrm{BE}$ were determined in an automated way by means of gas equipment.

The AG was calculated using the formula $\left(\mathrm{Na}^{+}\right.$ $\left.+\mathrm{K}^{+}\right)-\left(\mathrm{Cl}^{-}+\mathrm{HCO}_{3}^{-}\right)(13)$ and the metabolic hydrogen ions $\left(\mathrm{M}^{+} \mathrm{H}\right)$ as total hydrogen ions (Htot) minus the $\mathrm{H}^{+}$derived from the $\mathrm{CO}_{2}$ $\left(\mathrm{H}^{+}-\mathrm{CO}_{2}\right) \cdot \mathrm{M}^{+} \mathrm{H}$ values greater than $+5 \mathrm{mmol} / \mathrm{L}^{2}$ correspond to a metabolic acidosis and a value less than $-2 \mathrm{mmol} / \mathrm{L}$ to a metabolic alkalosis (14).

The samples were processed at the Zairo Laboratory of the Zayma Clinic in Montería, Colombia.

Statistical analysis. Data were processed using descriptive statistics, and the arithmetic mean and standard deviation were determined for each of the measured indicators. The Duncan
Para determinar el tamaño de muestra se utilizó una tabla de distribución normal, con una confiabilidad estadística del $94 \%$ y con un error máximo permisible del 5\%, el tamaño de muestra final fue de 60 animales. Se evaluaron 60 vacas preñadas y sus respectivas crías en las cuatro fincas seleccionadas.

Toma y procesamiento de la muestra. Previa desinfección del área y adecuada sujeción del animal, se obtuvieron $5 \mathrm{ml}$ de sangre, de la vena umbilical en los terneros después del nacimiento sin que succionaran el calostro y en la vena coccígea de las vacas. El procedimiento se realizó con jeringas heparinizadas comerciales (200 $\mu$ l de heparina sódica), doblando la aguja para evitar formación de burbujas y las muestras conservadas en hielo fueron analizadas antes de 2 horas. Los datos de identificación fueron registrados en una hoja clínica individual. Entre 8 a 12 horas de nacidos se observó la presencia del síndrome diarreico. Para la realización de los procedimientos antes descritos se tuvo en cuenta la reglamentación consignada en la ley 84 de 1989 en lo referente al bienestar animal (17).

Los signos vitales del recién nacido se registraron por inspección directa usando la tabla 1 (18) y las variables de laboratorio necesarias para realizar los cálculos del EAB mediante ionograma y el método gasométrico.

Se utilizó un aparato de gases sanguíneos Rapidlab 348 (Lab. Bayer, Alemania), que trabaja con electrodos de ion selectivo directo y bandas de medición para los resultados de $\mathrm{pCO}_{2}, \mathrm{Na}^{+}$, $\mathrm{K}^{+}, \mathrm{Cl}^{-}$y $\mathrm{pH}$. El cálculo del bicarbonato y el EB se determinó de forma automatizada mediante un equipo de gases.

El AG se calculó según la fórmula $\left(\mathrm{Na}^{+}+\mathrm{K}^{+}\right)-\left(\mathrm{Cl}^{-}\right.$ $+\mathrm{HCO}_{3}^{-}$) (13) y los hidrogeniones metabólicos $\left(\mathrm{H}^{+} \mathrm{M}\right)$ como hidrogeniones totales (Htot) menos los $\mathrm{H}^{+}$derivados del $\mathrm{CO}_{2}\left(\mathrm{H}^{+}-\mathrm{CO}_{2}\right)$. Valores de

Table 1. Numeric rating system (expressed as a depression rating) used to rate vital signs in calves with metabolic acidosis (18).

\begin{tabular}{|c|c|c|c|c|}
\hline Variable & Exploration method & $\mathbf{0}$ & 1 & 2 \\
\hline Time to lift head & $\begin{array}{l}\text { Should not be more than a minute after } \\
\text { birth }\end{array}$ & Does not raise head & Raises it but keeps resting & Raised and moving \\
\hline Suction reflex & Introduce finger in its mouth & Absent & Present, weak or not sustained & Stays strong \\
\hline Response to stimulus & $\begin{array}{l}\text { Pink croup } \\
\text { Press at the base of the ear } \\
\text { Drip water in ear }\end{array}$ & Does not react & Reacts weakly to all three & Reacts well to all three \\
\hline Interest in surroundings & Looks at everything in its surroundings & Detached & Little interest & Looks at everything \\
\hline Time to try to stand up & Spontaneously in the first 20 minutes & Does not stand & Does it in time but weakly & Does it in time \\
\hline
\end{tabular}


test for the multiple comparisons of means was used when necessary. In addition, a Pearson correlation was developed to establish the degree of association between $\mathrm{pH}, \mathrm{AG}, \mathrm{BE}$ and $\mathrm{M}^{+} \mathrm{H}$ in calves, cows and both. Also, the indexes of the newborn were determined by comparing proportions. Statistical software SPSS, version 16, was used (19).

\section{RESULTS}

Descriptive statistics of $A B B$ in cows and calves. In table 2 the medium, minimum and maximum values are observed of the $A B B$ in cows with diarrheic backgraunds and calves, as well as a comparison with reference values. In cows only the $\mathrm{pCO}_{2}(39.63 \mathrm{~mm} / \mathrm{Hg})$ diminished in comparison with the reference values (7) (Table $2)$. On the other hand, in calves the concentration of electrolytes $\mathrm{Na}^{+}(144.33 \mathrm{mEq} / \mathrm{L})$ and $\mathrm{Cl}^{-}$ $(104.23 \mathrm{mEq} / \mathrm{L})$ and $A G(18.95 \mathrm{mEq} / \mathrm{L})$ increased in comparison with the reference values (20); nevertheless, in these animals a reduction of $\mathrm{pH}$ (7.38), HCO-3 (23.57 mEq/L), pCO2 (44.97 mm/ $\mathrm{Hg})$ and $\mathrm{BE}(0.47 \mathrm{mEq} / \mathrm{L})$ was found.

Table 2. Descriptive statistic of $A B B$ in cows and calves on farms in Montería, Córdoba, Colombia.

\begin{tabular}{|c|c|c|c|c|c|}
\hline $\begin{array}{c}\text { Animals } \\
\text { Cows }(n=60)\end{array}$ & Average & SD \pm & Minimum & Maximum & $\begin{array}{c}\text { Reference } \\
\text { values* }\end{array}$ \\
\hline $\mathrm{pH}$ & 7.41 & 0.060 & 7.21 & 7.54 & 7.31 to 7.53 \\
\hline $\mathrm{Na}^{+}(\mathrm{mEq} / \mathrm{L})$ & 145.77 & 3.628 & 138.00 & 156.00 & 132 to 152 \\
\hline $\mathrm{K}^{+}(\mathrm{mEq} / \mathrm{L})$ & 4.58 & 0.439 & 3.66 & 6.19 & 3.9 to 5.8 \\
\hline $\mathrm{Cl}^{-}(\mathrm{mEq} / \mathrm{L})$ & 106.21 & 3.420 & 98.00 & 113.00 & 97 to 111 \\
\hline $\mathrm{HCO}_{3}{ }^{-}(\mathrm{mEq} / \mathrm{L})$ & 23.80 & 2.630 & 12.50 & 29.20 & 17 to 29 \\
\hline $\mathrm{pCO}_{2}(\mathrm{~mm} / \mathrm{Hg})$ & 39.63 & 6.979 & 27.50 & 56.10 & 41 to 46 \\
\hline $\mathrm{AG}(\mathrm{mEq} / \mathrm{L})$ & 19.67 & 4.789 & 9.89 & 35.27 & 10 to 20 \\
\hline $\mathrm{BE}(\mathrm{mEq} / \mathrm{L})$ & 0.49 & 4.166 & -17.20 & 6.60 & 0 to 6 \\
\hline $\mathrm{M}^{+} \mathrm{H}$ & -0.84 & 3.800 & -7.94 & 11.53 & -2 to $5 * * *$ \\
\hline Calves $(n=60)$ & Average & SD \pm & Minimum & Maximum & $\begin{array}{l}\text { Reference } \\
\text { values** }\end{array}$ \\
\hline $\mathrm{pH}$ & 7.38 & 0.052 & 7.22 & 7.52 & 7.39 to 7.42 \\
\hline $\mathrm{Na}^{+}(\mathrm{mEq} / \mathrm{L})$ & 144.33 & 2.932 & 138.00 & 153.00 & 136 to 137 \\
\hline $\mathrm{K}^{+}(\mathrm{mEq} / \mathrm{L})$ & 4.54 & 0.466 & 3.54 & 5.85 & 4.36 to 4.58 \\
\hline $\mathrm{Cl}^{-}(\mathrm{mEq} / \mathrm{L})$ & 104.23 & 3.738 & 93.00 & 111.00 & 98 to 99 \\
\hline $\mathrm{HCO}_{3}^{-}(\mathrm{mEq} / \mathrm{L})$ & 23.57 & 2.299 & 16.10 & 28.40 & 29 to 30 \\
\hline $\mathrm{pCO}_{2}(\mathrm{~mm} / \mathrm{Hg})$ & 44.97 & 5.491 & 28.00 & 57.60 & 46 to 48 \\
\hline $\mathrm{AG}(\mathrm{mEq} / \mathrm{L})$ & 18.95 & 4.354 & 11.80 & 29.93 & 11 to 12 \\
\hline $\mathrm{BE}(\mathrm{mEq} / \mathrm{L})$ & 0.47 & 3.018 & -10.40 & 6.00 & 4.84 to 6.08 \\
\hline $\mathrm{M}+\mathrm{H}$ & -1.60 & 3.631 & -8.39 & 9.91 & -2 to $5^{* * *}$ \\
\hline
\end{tabular}

Average and $\mathrm{SD} \pm$ : standard deviation.

$\mathrm{pCO}_{2}$ : $\mathrm{CO}_{2}$ Pressure; BE: Excess of Base; AG: Anion Gap. $\mathrm{M}^{+} \mathrm{H}$ : metabolic hydrogen ions.

*Reference values for cows (7)

$*$ Reference values for cows (7)
$* *$ Reference values for calves (20)

*** Reference for $\mathrm{M}^{+} \mathrm{H}$ (14).
$\mathrm{H}^{+} \mathrm{M}$ superiores $\mathrm{a}+5 \mathrm{mmol} / \mathrm{L}$, corresponde a una acidosis metabólica y un valor menor de -2 $\mathrm{mmol} / \mathrm{L}$ a una alcalosis metabólica (14).

Las muestras se procesaron en el laboratorio Zairo de la clínica Zayma en Montería, Colombia.

Análisis estadísticos. Los datos se procesaron mediante estadística descriptiva, se determinó la media aritmética y la desviación estándar a cada uno de los indicadores medidos. En los casos necesarios se utilizó la dócima de Duncan para la comparación múltiple de medias. Además, se desarrolló una correlación de Pearson para establecer el grado de asociación entre pH, AG, $E B$ e $\mathrm{H}^{+} \mathrm{M}$ en terneros, vacas y ambos. También se determinaron los índices del recién nacido mediante comparación de proporciones. Se usó el software estadístico SPSS versión 16 (19).

\section{RESULTADOS}

Estadística descriptica del EAB de vacas y terneros. En la tabla 2 se observan los valores medios, mínimos y máximos de los indicadores del $E A B$ en vacas con antecedentes diarreicos y terneros; así como una comparación con valores de referencia. En las vacas solo la $\mathrm{pCO}_{2}$ (39.63 $\mathrm{mm} / \mathrm{Hg}$ ) disminuyó en correspondencia con los valores de referencia (7)(Tabla 2). Por otro lado, en terneros la concentración de los electrolitos $\mathrm{Na}^{+}(144.33 \mathrm{mEq} / \mathrm{L})$ y Cl- $(104.23 \mathrm{mEq} / \mathrm{L})$ y del AG (18.95 mEq/L) aumentó en correspondencia con los valores de referencia (20); sin embargo, en estos animales, se encontró una disminución del $\mathrm{pH}(7.38), \mathrm{HCO}_{3}^{-}(23.57 \mathrm{mEq} / \mathrm{L}), \mathrm{pCO}_{2}(44.97$ $\mathrm{mm} / \mathrm{Hg})$ y $E B(0.47 \mathrm{mEq} / \mathrm{L})$.

Correlación de pH, AG, EB e $\mathrm{H}^{+} \mathrm{M}$ en vacas y terneros. La tabla 3 muestra las correlaciones del $E A B$ en terneros y vacas. $E l \mathrm{pH}(\mathrm{t})$ mostró una correlación positiva con el EB $(v)(p<0.05)$ y una correlación negativa con el $A G(v)(p<0.05)$ y los $H^{+} M(v)(p<0.01)$. También, el $A G(t)$ influyó en una correlación positiva con el AG $(v)(p<0.01)$ y los $\mathrm{H}^{+} \mathrm{M}(\mathrm{v})(\mathrm{p}<0.05)$. Además, se observó una correlación negativa entre el EB ( $t$ ) y con los $\mathrm{H}^{+} \mathrm{M}$ (v) $(p<0.05)$. De la misma manera los $\mathrm{H}^{+} \mathrm{M}(\mathrm{t})$

Table 3. Correlation of $\mathrm{pH}, \mathrm{AG}, \mathrm{BE}$ and $\mathrm{H}^{+} \mathrm{M}$ in cows $(n=60)$ and calves $(n=60)$.

\begin{tabular}{ccccc}
\hline Indicators & pH (v) & AG (v) & BE (v) & $\mathbf{H}^{+} \mathbf{M}(\mathbf{v})$ \\
\hline $\mathrm{pH}(\mathrm{t})$ & 0.11 & $-0.31^{*}$ & $0.26 *$ & $-0.30^{* *}$ \\
$\mathrm{AG}(\mathrm{t})$ & -0.10 & $0.54 * *$ & -0.17 & $0.14^{*}$ \\
$\mathrm{BE}(\mathrm{t})$ & 0.17 & -0.20 & 0.15 & $-0.31^{*}$ \\
$\mathrm{M}^{+} \mathrm{H}(\mathrm{t})$ & $-0.33^{*}$ & 0.08 & -0.13 & $0.33^{*}$ \\
\hline
\end{tabular}

** $\mathrm{p}<0.01 ; * \mathrm{p}<0.05$ (Pearson) V: cow; t: calf 
Correlation of $\mathbf{p H}, \mathrm{AG}, \mathrm{BE}$ and $\mathrm{M}^{+} \mathrm{H}$ in cows and calves. Table 3 shows the comparison with ABB in calves and cows. The $\mathrm{pH}(\mathrm{t})$ had a positive correlation with $B E(v)(p<0.05)$ and a negative correlation with $A G(v)(p<0.05)$ and the $M^{+} H$ (v) $(p<0.01)$. Also, the $A G(t)$ affected a positive correlation with $A G(v)(p<0.01)$ and $M^{+} H(v)$ $(p<0.05)$. Additionally, a negative correlation between $B E(t)$ and with $M^{+} H(v)(p<0.05)$ was observed. In the same way $\mathrm{M}^{+} \mathrm{H}(\mathrm{t})$ indicated a negative and positive correlation with reference to $\mathrm{pH}(\mathrm{v})(\mathrm{p}<0.05)$ and $\mathrm{M}^{+} \mathrm{H}(\mathrm{v})(\mathrm{p}<0.05)$. The finding of a high correlation between the cows with their respective newborns for AG $\left(0.54^{* *}\right)$ was noteworthy.

Tables 4 and 5 indicate the correlations between the ABB in cows and calves separately. All the correlated indicators showed significant differences $(p<0.05)$ and the same correlational tendencies.

Table 4. Correlation of $\mathrm{pH}, \mathrm{AG}, \mathrm{BE}$ and $\mathrm{M}^{+} \mathrm{H}$ in cows $(\mathrm{n}=60)$.

\begin{tabular}{cccc}
\hline Indicators & AG & BE & $\mathbf{M}^{+} \mathbf{H}$ \\
\hline $\mathrm{pH}$ & $-0.497 * *$ & $0.310^{*}$ & $-0.431 * *$ \\
$\mathrm{AG}$ & & $-0.514 * *$ & $0.422 * *$ \\
$\mathrm{BE}$ & & & $-0.671 * *$ \\
\hline$* * \mathrm{p}<0.01 ; * \mathrm{p}<0.05($ Pearson) & &
\end{tabular}

** $\mathrm{p}<0.01 ; * \mathrm{p}<0.05$ (Pearson).

Table 5. Correlation of $\mathrm{pH}, \mathrm{AG}, \mathrm{BE}$ and $\mathrm{M}^{+} \mathrm{H}$ in calves $(n=60)$.

\begin{tabular}{cccc}
\hline Indicators & AG & BE & $\mathbf{M}^{+} \mathbf{H}$ \\
\hline $\mathrm{pH}$ & $-0.600^{* *}$ & $0.595^{* *}$ & $-0.467^{* *}$ \\
$\mathrm{AG}$ & & $-0.378^{* *}$ & $0.268^{*}$ \\
$\mathrm{BE}$ & & $-0.761^{* *}$ \\
\hline$* * \mathrm{p}<0.01 ; * \mathrm{p}<0.05$ (Pearson) & &
\end{tabular}

The $\mathrm{pH}$ indicated negative correlations with $\mathrm{AG}$ $(p<0.05)$ and $\mathrm{M}^{+} \mathrm{H}(\mathrm{p}<0.01)$ and positive with BE $(p<0.05)$. However, AG showed a negative correlation with BE $(p<0.01)$ and a positive one for $\mathrm{M}^{+} \mathrm{H}(\mathrm{p}<0.05 ; \mathrm{p}<0.01)$. Also, a negative correlation was observed for the $B E$ and $M^{+} H$ indicators $(p<0.01)$ (Tables 4 and 5$)$.

ABB indicators in cows and calves at four farms in the municipality of Montería. The $\mathrm{pH}$ and $\mathrm{BE}$ in cows and calves and $\mathrm{M}^{+} \mathrm{H}$ in calves did not show significant differences $(p>0.05)$ between the farms in the study; nevertheless, AG (cow) increased in Farm $C$ and showed statistical differences $(p<0.05)$ with Farm D. In cows, $M^{+} H$ indicated significant differences $(p<0.05)$ for Farms $B$ and $C$. On the other hand, in calves, AG showed notable differences $(p<0.05)$ between the same farms with relation to Farms $A$ and indicaron una correlación negativa y positiva con respecto al $\mathrm{pH}(\mathrm{v})(\mathrm{p}<0.05) \mathrm{e} \mathrm{H}^{+} \mathrm{M}(\mathrm{v})(\mathrm{p}<0.05)$. Se destaca el hallazgo de una correlación alta entre las vacas con sus respectivos neonatos para el AG $(0.54 * *)$.

Las tablas 4 y 5 indican las correlaciones del EAB en las vacas y los terneros por separado. Todos los indicadores correlacionados mostraron diferencias significativas $(p<0.05)$ y las mismas tendencias correlacionales.

El pH indicó correlaciones negativas con el AG $(p<0.05)$ y los $\mathrm{H}^{+} \mathrm{M}(\mathrm{p}<0.01)$ y positivas con el EB $(p<0.05)$. Sin embargo, el AG mostró una correlación negativa con el EB $(p<0.01)$ y positiva para los $\mathrm{H}^{+} \mathrm{M}(\mathrm{p}<0.05 ; \mathrm{p}<0.01)$. También, se observó una correlación negativa para los indicadores $\mathrm{EB}$ e $\mathrm{H}^{+} \mathrm{M}(\mathrm{p}<0.01)($ Tablas 4 y 5$)$.

\section{Indicadores del EAB de vacas y terneros en} cuatro fincas del municipio de Montería. El $\mathrm{pH}$ y EB en vacas y terneros e $\mathrm{H}^{+} \mathrm{M}$ en terneros se mantuvieron sin diferencias significativas $(p>0.05)$ entre las fincas de estudio; sin embargo, AG (vaca) aumentó en la finca $C y$ mostró diferencias estadísticas $(p<0.05)$ con la finca $D$. En las vacas los $\mathrm{H}^{+} \mathrm{M}$ indicaron diferencias significativas $(p<0.05)$ para las fincas $B$ y $C$. Por otro lado, en terneros el AG mostró diferencias notables $(p<0.05)$ entre las mismas fincas con relación a las fincas $A$ y $D$ (Tabla 6). Destacar que el AG mostró diferencias significativas en vacas y terneros en las mismas zonas de estudio.

Índices del recién nacido. La proporción de terneros en cada índice según los resultados subjetivos se observa en la figura 1. Los signos levantar cabeza, respuesta a estímulo, interés por el entorno y tiempo para colocarse en estación mostraron las mayores proporciones $(p<0.05)$ en el grupo de calificación dos, según el sistema de calificación numérica (Tabla 1), contrario al

Table 6. ABB indicators in cows and calves on four farms in the municipality of Montería.

\begin{tabular}{|c|c|c|c|c|c|c|}
\hline \multirow{2}{*}{ Indicators } & \multicolumn{4}{|c|}{ Farms } & \multirow{2}{*}{ SE \pm} & \multirow{2}{*}{ P Value } \\
\hline & A & B & C & D & & \\
\hline \multicolumn{7}{|l|}{ Cows } \\
\hline $\mathrm{pH}$ & 7.42 & 7.40 & 7.41 & 7.43 & 0.016 & 0.527 \\
\hline$A G$ & $20.64^{\mathrm{ab}}$ & $20.50^{\mathrm{ab}}$ & $22.46^{a}$ & $17.75^{\mathrm{b}}$ & 1.210 & 0.041 \\
\hline $\mathrm{M}^{+} \mathrm{H}$ & $0.18^{\mathrm{ab}}$ & $0.45^{\mathrm{a}}$ & $-0.259^{b}$ & $-1.40^{\mathrm{ab}}$ & 0.954 & 0.099 \\
\hline $\mathrm{BE}$ & -1.75 & -0.83 & 1.42 & -8.020 & 1.06 & 0.192 \\
\hline \multicolumn{7}{|l|}{ Calves } \\
\hline $\mathrm{pH}$ & 7.38 & 7.36 & 7.37 & 7.38 & 0.014 & 0.300 \\
\hline$A G$ & $19.04^{\mathrm{b}}$ & $22.37^{\mathrm{a}}$ & $23.73^{a}$ & $19.12^{\mathrm{b}}$ & 1.103 & 0.006 \\
\hline $\mathrm{M}^{+} \mathrm{H}$ & -1.81 & -0.33 & -1.36 & -2.90 & 0.930 & 0.280 \\
\hline $\mathrm{BE}$ & 0.74 & -1.08 & 0.61 & 1.60 & 0.750 & 0.097 \\
\hline
\end{tabular}

$a, b$ Means with different letters in the same row differ by $p<0.05$ (Duncan). 
D (Table 6). It is noteworthy that AG showed significant differences in cows and calves in the same areas of the study.

Indexes of the newborn. The proportion of calves in each index according to the subjective results is observed in figure 1 . Signs such as raising the head, responding to stimulus, interest in the environment and time to get into station are shown in greater proportions $(\mathrm{p}<0.05)$ in rating group two, according to the numeric rating system (Table 1 ), on the opposite of the suction reflex $(p<0.05)$, which showed significant values in rating group one. It is noteworthy that except for the suction reflex sign, other indexes did not indicate animals (calves) in group zero.

\section{DISCUSSION}

The results obtained showed that the $A B B$ indicators were generally within the physiological reference values according to the literature consulted $(7,14,20)$; however, in calves the following analytes did not match: $\mathrm{pH}, \mathrm{pCO} 2, \mathrm{HCO}_{3}^{-}, \mathrm{AG}$, and $\mathrm{BE}$.

The increase of plasmatic $\mathrm{Na}^{+}$can be explained by a raise in the level of aldosterone at birth, $\mathrm{Cl}^{-}$follows $\mathrm{Na}^{+}$; these results are similar to those reported by Herosimczyk et al (21).

In calves, the decrease of $\mathrm{pH}, \mathrm{pCO}_{2}$ and $\mathrm{HCO}_{3}^{-}$ (Table 2 ) suggests a condition of metabolic acidosis, which agrees with that obtained by Lisboa et al (22) in newborn animals; the low pH stimulates the increase of ventilation which involves a decrease of $\mathrm{PCO}_{2}$.

The increase of $A G$ and the reduction of the $B E$ (Table 2 ) in some calves could indicate a possible metabolic acidosis; this condition is caused, among other reasons, by diarrhea, which causes alterations in the hemogasometric parameters such as the decrease of serum bicarbonate, BE and increases AG; these results are similar to those obtained by Freitas (20).

If this state is maintained, the calves would enter a state of serious metabolic acidosis, which would mean death for most of the animals due to metabolic alterations. In Farm B there were two calves that died from diarrhea, with low concentrations of $\mathrm{pH}$ and $\mathrm{BE}$ (data not shown).

On the other hand, a direct relationship with the AG value was found between cows and their respective newborns (Table 3 ). At the time of

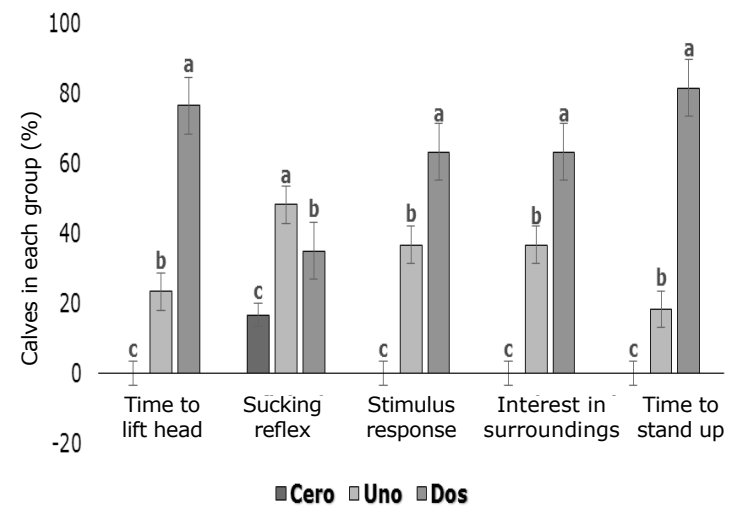

Figure 1. Index of newborn calves (calves, $N=60$ ).

reflejo de succión $(p<0.05)$ que mostró valores significativos en el grupo de calificación uno. Destacar, que excepto el signo de reflejo de succión, los otros índices no indicaron animales (terneros) en el grupo cero.

\section{DISCUSIÓN}

Los resultados obtenidos mostraron que los indicadores del $E A B$ en su mayoría estuvieron dentro de los valores fisiológicos de referencia de acuerdo con la literatura consultada $(7,14,20)$; sin embargo, en los terneros no coincidieron los siguientes analitos: $\mathrm{pH}, \mathrm{pCO}_{2}, \mathrm{HCO}^{-}{ }^{\prime} \mathrm{AG}$, y $\mathrm{EB}$.

El incremento de $\mathrm{Na}^{+}$plasmático puede ser explicado por un aumento en el nivel de aldosterona al nacimiento, el $\mathrm{Cl}^{-}$sigue al $\mathrm{Na}^{+}$; estos resultados son similares a los reportados por Herosimczyk et al (21).

En los terneros la disminución del $\mathrm{pH}$, de la $\mathrm{pCO}_{2}$ y del $\mathrm{HCO}_{3}^{-}$(Tabla 2) sugieren una condición de acidosis metabólica; lo cual concuerda con lo obtenido por Lisboa et al (22) en animales recién nacidos; el pH bajo estimula el aumento de la ventilación lo que conlleva a un descenso de la $\mathrm{PCO}_{2}$.

El aumento del AG y la disminución del EB (Tabla 2) en algunos terneros podría indicar una posible instauración de acidosis metabólica; esta condición causada entre otras por diarrea imprime al animal alteraciones en los parámetros hemogasométricos como la reducción del bicarbonato sérico, el EB y el aumento del AG; estos resultados son similares a los obtenidos por Freitas (20).

De mantenerse este estado, los terneros entrarían en estado de acidosis metabólica grave, lo que conllevaría a la mayoría de las crías al fallecimiento por alteraciones metabólicas. En la finca B hubo dos terneros muertos por diarrea, los cuales 
birth the fetus suffered metabolic acidosis as a consequence of suspending the umbilical flow of blood, the effort made during birth established an anaerobic metabolic process, at least until the beginning of respiratory functions (3).

The correlations in cows and calves between $\mathrm{pH}$ with $\mathrm{AG}, \mathrm{BE}$ and $\mathrm{M}^{+} \mathrm{H}$ (Tables 4 and 5 ) is important, since it allows using any technique to identify $A B B$ in bovines, differentiate and rate metabolic acidosis with $A G$ and $M^{+} H$, and $B E$ is a fundamental indicator to diagnose and establish corrective therapies in ABB (23).

The significant differences $(p<0.05)$ in $A G$ in calves and cows between Farms $B$ and $C$ regarding Farms $A$ and $D$ (Table 6 ) can be explained due to the geographic location, since Farms $B$ and $C$ are found in areas that are prone to flooding, which can predispose the appearance of acidosis, given that flooding causes anoxia, which provokes the formation of volatile sulphuric acid (24); on the other hand, flooding can facilitate the presence of infectious diseases.

The correlation between the different variables $(\mathrm{pH}, \mathrm{BE}, \mathrm{AG})$ with $\mathrm{M}^{+} \mathrm{H}$ is important from a practical point of view, since only by determining the $\mathrm{pH}$ and the $\mathrm{pCO}_{2}$ can the $\mathrm{ABB}$ be evaluated (25); also, it opens the way to use $\mathrm{M}^{+} \mathrm{H}$ as part of the ABB diagnosis in bovines in field conditions where analytical tools are not available.

Metabolic acidosis causes clinical symptoms that are attributable to a neurological dysfunction (26). Diarrhea is the most important and frequent cause of metabolic acidosis in calves and one of the principal neurological changes in an acidotic calf is the loss of the suction reflex (27). In this sense, studies have been done to indicate the association between systemic acidosis with the deterioration of the suction reflex (28) and between BE with changes in attitude and behavior (29) as well as the relationship between dehydration and the posture of the animal (30). Therefore, these vital signs of the newborn could be used as clinical physiological indicators of newborn acidosis in bovines.

It is concluded that in the studied population, ABB analyte measurements in bovines were similar to the reference consulted and could be used as a reference for future studies. Metabolic acidosis is suggested in calves keeping in mind the values of $A G$ and $B E$ and with $\mathrm{M}^{+} \mathrm{H}$; this last variable that rates the tenían bajas concentraciones de $\mathrm{pH}$ y EB (datos no mostrados).

Por otra parte, se encontró una relación directa en el valor del AG entre las vacas y sus respectivos terneros (Tabla 3). En el momento del parto el feto sufre de acidosis metabólica como consecuencia de la suspensión del flujo de sangre umbilical, el esfuerzo realizado durante el parto establece un proceso metabólico anaerobio, por lo menos hasta el inicio de la función respiratoria (3).

La correlación en vacas y terneros entre el $\mathrm{pH}$ con AG, EB e H*M (Tablas 4 y 5); es importante, ya que permite el empleó de cualquiera de las técnicas para conocer el EAB en bovinos, diferenciar y cuantificar la acidosis metabólica con el $A G$ e $\mathrm{H}^{*} \mathrm{M}$ y el EB es un indicador fundamental para el diagnóstico e instauración de terapias correctivas en el EAB (23).

Las diferencias significativas $(p<0.05)$ en el $A G$ en terneros y vacas entre las fincas $B$ y $C$ con respecto a las fincas $A$ y $D$ (Tabla 6), podrían ser explicadas por la ubicación geográfica, ya que las fincas B y C se encuentran en zonas inundables, lo que puede predisponer la instauración de la acidosis, dado que en la inundación se producen condiciones de anoxia, lo que provoca la formación de sulfuro ácido volátil (24); de otro lado, las inundaciones puede facilitar la presencia de enfermedades infecciosas.

La correlación entre las diferentes variables $(\mathrm{pH}$, $\mathrm{EB}, \mathrm{AG}$ ) con $\mathrm{H}^{+} \mathrm{M}$ es importante desde el punto de vista práctico, ya que con sólo determinar el $\mathrm{pH}$ y la $\mathrm{pCO}_{2}$ se puede evaluar el EAB (25); además, abre el camino para el uso de los $\mathrm{H}^{+} \mathrm{M}$ como parte del diagnóstico de EAB en bovinos en condiciones de campo donde las herramientas analíticas no están disponibles.

La acidosis metabólica causa signos clínicos atribuibles a una disfunción neurológica (26). La diarrea es la causa más importante y frecuente de acidosis metabólica en terneros y uno de los principales cambios neurológicos en el ternero acidótico es la pérdida del reflejo de succión (27). En este sentido, se han realizado estudios para indicar asociación entre la acidosis sistémica con el deterioro del reflejo de succión (28) y entre el EB con cambios de actitud y comportamiento (29), así como relación entre la deshidratación y la postura del animal (30). Por lo tanto estos signos vitales del recién nacido podrían ser utilizados como indicadores clínico-fisiológicos de la acidosis neonatal de los bovinos.

Se concluye que en la población estudiada, la medición de los analitos del EAB en bovinos fue similar a la referencia consultada y se podrían utilizar como referencia para futuros trabajos. 
metabolic component of $A B B$ is evaluated for the first time in bovines. When evaluating the indexes of the newborn in bovines by means of vital signs, opens the possibility of using them in a predictive way, especially the suction reflex, in order to prevent the newborn acidosis in calves under field conditions without recurring to a hemogasometric determination.

\section{Acknowledgements}

To the research and extension office of the Universidad de Córdoba, Colombia. FMV-05-06.
Se sugiere acidosis metabólica en los terneros teniendo en cuenta los valores de AG y EB y con $\mathrm{H}^{+} \mathrm{M}$; esta última variable que cuantifica el componente metabólico del $E A B$, se evalúa por primera vez en bovinos. Al evaluar los índices del recién nacido en bovinos mediante signos vitales abre la posibilidad de utilizarlos de una manera predictiva, especialmente el reflejo de succión, para prevenir la acidosis neonatal en los terneros en condiciones de campo sin recurrir a la determinación hemogasométrica.

\section{Agradecimientos}

A la oficina de investigación y extensión de la Universidad de Córdoba, Colombia. FMV-05-06.

\section{REFERENCES}

1. Cho YI1, Yoon KJ. An overview of calf diarrhea - infectious etiology, diagnosis, and intervention. J Vet Sci 2014;15(1):1-17.

2. Lorenz I, Fagan J, More SJ. Calf health from birth to weaning. II. Management of diarrhea in pre-weaned calves. Ir Vet J $2011 ; 64(1): 1-6$.

3. Murray CF, Leslie KE. Newborn calf vitality: risk factors, characteristics, assessment, resulting outcomes and strategies for improvement. Vet J 2013; 198(2):322-328.

4. Baquero-Parrado JR. Diarrea neonatal indiferenciada en terneros: consideraciones sobre su prevención en campo. Vet Zoo Tec 2008; 2(2):59-68.

5. Carrillo R, Visoso P. Equilibrio ácido-base. Conceptos actuales. Rev Asoc Mex Med Crit y Ter Int 2006; 20(4):184-192

6. Hasselbalch KA. Die Berechnung der wasserstoltzahl des blutes ous der freien und gebunden kohlensaure desselben, und die sauerstoltbindung des blutes als function der wassertozahl. Biochem Z 1917; 78:112-144.

7. Kaneko J, Harvey JW, Bruss ML. Clinical biochemistry of domestic animals. $6^{\mathrm{a}} \mathrm{ed}$. Amsterdam: Elsevier Inc; 2008.

8. Oetzel GR. Monitoring and testing dairy herds for metabolic disease. Vet. Clin. North Am., Food Anim Pract 2004; 20(3):651-674.
9. Singer RB. Haslings AB. An improved clinic method for the estimation of disturbances of the acid-base balance of human blood. Medicine (Baltimore) 1948; 27(2):223-242.

10. Andersen OS, Engel K, Jorgensen K, Astrup $P$. A micro method for determination of $\mathrm{pH}$, carbon dioxide tension, base excess and standard bicarbonate in capillary blood. Scand J Clin Lab Invest 1960; 12:172-176.

11. Bookallil MJ. $\mathrm{pH}$ of the blood: acid base balance. [en línea]. University of Sydney. 2010. (acceso septiembre de 2013); URL disponible en: http://www.anaesthesia. med.usyd.edu.au/resources/lectures/ acidbase_mjb/acidbase.html

12. Emmelt M. Narins RG. CIinical use of the Anión Gap. Medicine (Baltimore) 1977; 56(1):38-54.

13. Radostits OM, Gay CC, Hinchcliff KW. Veterinary Medicine. A textbook of the diseases of cattle, horses, sheep, pigs, and goats. $10^{\text {th }}$ ed. Philadelphia: Elsevier Inc; 2007.

14. Cruz LE, Diaztagle JJ, Giraldo E, Melo CE, Sprockel JJ. Comparación de diferentes medidas para el abordaje fisiológico del estado ácido-base en pacientes críticos: papel de los hidrogeniones metabólicos. Acta Colombiana de Cuidado Intensivo 2009; 9(2):131-144. 
15. Kraut JA, Madias NE. Metabolic acidosis: pathophisiology, diagnosis and management. Nat Rev Nephrol 2010; 6:274-285. doi: 10.1038/nrneph.2010.33

16. Resolución 002341. [en linea]. Bogotá, Colombia: ICA-FEDEGAN. Instituto Colombiano Agropecuario; 2007. URL Disponible en: http://www.slideshare.net/ Fedegan/resolucion-2341

17. Mrad de Osorio A. Ética en la investigación con modelos animales experimentales. Revista Colombiana de Bioética 2006; 1(1):163-184.

18. Kasari TR, Naylor JM. Further studies on the clinical features and clinicopathological findings of a syndrome of metabolic acidosis with minimal dehydration in neonatal calves. Can J Vet Res 1986; 50(4):502-508.

19. SPSS Inc. SPSS for Windows Version 16.0. Chicago, Illinois, USA: SPSS Inc; 2007.

20. Freitas, MD. Avaliação dos parâmetros clínicos e de patologia clínica em bezerros naturalmente infectados com diarréia neonatal. [Dissertação Mestrado em Medicina Veterinária]. Brasil: Universidade Federal de Minas Gerais, Escola de Veterinária; 2009. URL Disponible en: http://www.bibliotecadigital.ufmg.br/ dspace/handle/1843/SSLA-83KKES

21. Herosimczyk A, Lepczynski A, DratwaChalupnik A, Kurpinska A, Klonowska A, Skrzypczak WF. Age-related changes of selected blood biochemical indicators in dairy calves during their first week of life. Folia Biol (Krakow) 2011; 59(1-2):25-30.

22. Lisboa JAN, Benesi FJ, Leal MLR, Teixeira CMC.Leal. Efeito da idade sobre o equilibrio ácido básico de bezerras sadias no primeiro mes de vida. Braz J Vet Res Anim Sci 2002; 39(3):136-142.
23. Kirchner D, Schwedhelm L, Coenen $M$, Bachmann L. Dietary influences on the hydration and acid-base status of experimentally dehydrated dairy calves. Vet ] 2014; 199(2):251-257.

24. Poot A, Gillissen F, Koelmans A. Effects of flow regime and flooding on heavy metal availability in sediment and soil of a dynamic river system. Environ Pollut 2007; 148(3):779-787. doi:10.1016/j. envpol.2007.01.045

25. Effros RM. Stewart approach is not always a practical clinical tool. Anaesth Analg 2004; 98(1):271-272.

26. Nakagawa, M, Suzuki K, Taguchi K. Relationship between depression score and acid-base status in Japanese black calves with diarrhea. J Vet Med Sci 2007; 69(5):549-552.

27. Sobiech P, Rękawek W, Ali M, et al. Changes in blood acid-base balance parameters and coagulation profile during diarrhea in calves. Pol J Vet Sci 2013; 16(3):543-549.

28. Gentile A, Lorenz I, Sconza S, Klee W. Experimentally induced systemic hyperchloremic acidosis in calves. J Vet Intern Med 2008; 22(1):190-195.

29. Gómez De, Lofstedt J, Stämpfli HR, Wichtel M, Muirhead T, McClure JT. Contribution of unmeasured anions to acid-base disorders and its association with altered demeanor in 264 calves with neonatal diarrea. J Vet Intern Med 2013; 27(6):1604-1612.

30. Temiz M, Altuğ N, Yüksek N. Relationship between degree of anemia and blood gases in cattle with theileriosis. Turk J Vet Anim Sci 2014; 38:82-87. 